\title{
Photosynthetic and enzymatic metabolism of Schinus terebinthifolius Raddi seedlings under water deficit
}

\author{
Metabolismo fotossintético e enzimático das mudas de Schinus terebinthifolius \\ Raddi sob déficit hídrico
}

\author{
Danieli Pieretti Nunes ${ }^{1}$, Silvana de Paula Quintão Scalon ${ }^{1}$ \\ Daiane Mugnol Dresch ${ }^{1 *}$, Carla Regina Baptista Gordin ${ }^{1}$
}

\author{
'Universidade Federal da Grande Dourados/UFGD, Faculdade de Ciências Agrárias, Dourados, MS, Brasil \\ ${ }^{*}$ Corresponding author: daiamugnol@hotmail.com \\ Received in March 7, 2017 and approved in August 28, 2017
}

\begin{abstract}
Schinus terebinthifolius Raddi is a tree species that can be used in the recovery of degraded areas, as it exhibits rapid growth and has a very expansive root system, facilitating water uptake from the deeper layers of the soil. The objective of this study was to evaluate photosynthesis and enzymatic activity in S. terebinthifolius seedlings under conditions of water deficit and their potential to recover following re-irrigation. The experiment was conducted in a greenhouse under a plastic covering where plants were distributed into two groups: Group 1 - control plants, where irrigation was maintained at 70\% of the water retention capacity, and Group 2 - stressed plants, where irrigation was suspended until the photosynthetic rate neared zero, followed by rehydration for 12 days, then a further suspension of irrigation. At the beginning of the experiment and during the suspension of irrigation and rehydration, plants were evaluated for gas and antioxidant enzyme exchanges. Hydric stress significantly reduced photosynthesis, stomatal transpiration conductance, carboxylation efficiency of Rubisco, and the chlorophyll content of the S. terebinthifolius plants. Following rehydration, plants recovered the carboxylation efficiency of Rubisco, but not the photosynthetic rate. Antioxidant enzyme activity increased in both the aerial part and the root in response to water deficit.
\end{abstract}

Index terms: Gas exchanges; antioxidant enzyme; stress deficit.

\begin{abstract}
RESUMO
Schinus terebinthifolius Raddi é uma espécie arbórea que pode ser utilizada em recuperação de áreas degradas, sendo uma espécie de rápido crescimento com um sistema radicular bem expansivo o que facilita captar águas nas camadas mais profundas do solo. $\mathrm{O}$ objetivo deste trabalho foi avaliar o metabolismo fotossintético e enzimático das mudas de $S$. terebinthifolius sob condições de déficit hídrico e seu potencial de recuperação após a retomada de irrigação. O experimento foi realizado em casa de vegetação sob cobertura plástica onde os vasos foram distribuídos em dois lotes sendo: 1 - Controle, onde a irrigação das plantas foi mantida a $70 \%$ da capacidade de retenção de água e o lote 2 - Estresse, onde a suspensão da irrigação foi mantida até que a taxa fotossintética apresentasse níveis próximos de zero seguida de reidratação por 12 dias e nova suspensão da irrigação. No início do experimento e na suspensão da irrigação e reidratação, as plantas foram avaliadas quanto as trocas gasosas e enzimas antioxidantes. O estresse hídrico reduz significativamente a fotossíntese, a transpiração condutância estomática, a eficiência de carboxilação da rubisco e os teores de clorofila das plantas de S. terebinthifolius. As enzimas antioxidantes aumentaram tanto na parte aérea quanto na raiz em resposta ao déficit hídrico.
\end{abstract}

Termos para indexação: Trocas gasosas; enzimas antioxidantes; estresse hídrico.

\section{INTRODUCTION}

Schinus terebinthifolius is known as the Brazilian pepper tree or the rose pepper, mainly owing to the appearance of its fruits. It can be used in the recovery of degraded areas, as it demonstrates rapid growth and has a very expansive root system that facilitates water uptake from the deeper layers of the soil (Souza et al., 2013). In Brazil, this tree is found along the coast, from Pernambuco to Rio Grande do Sul (Oliveira; Araújo, 2007), and in the Amazônia and Minas Gerais regions (Carvalho et al.,
2013). However, there is limited information on the ecophysiology of the initial growth of this species.

Hydric stress occurs when low water availability affects physiological processes, such as transpiration, photosynthesis, stomatal opening, and abscisic acid (ABA) production (Costa; Marenco, 2007; Melcher et al., 2009). There is no universal mechanism for resistance to drought, as plants respond to water shortage through various adaptive processes, such as their capacity to reduce the water potential associated with morphological, anatomical, 
and physiological adaptations (Damayanthi; Mohotti; Nissanka, 2010; Anjun et al., 2011; Ashraf; Harris, 2013).

Water stress may involve the accumulation of reactive oxygen species (ROS) in plant cells, which triggers the production of antioxidant enzymes, such as superoxide dismutase (SOD), catalase (CAT), ascorbate peroxidase (APX), dehydroascorbate reductase (DHAR), and polyphenoloxidase (PPO). These defense mechanisms are employed to overcome the stress and restore normal metabolism (Soares; Machado, 2007, Ali; Ashraf, 2011; Karuppanapandian et al., 2011).

Considering the broad distribution of $S$. terebinthifolius, we hypothesized that it would exhibit tolerance to water deficit. Thus, the objective of this study was to evaluate changes in photosynthesis and enzymatic activity under water deficit conditions and the potential of S. terebinthifolius to recover upon rehydration.

\section{MATERIAL AND METHODS}

Seedlings were grown in $8 \mathrm{~kg}$ pots containing a substrate consisting of a mixture of soil (dystroferric Red Latosol), sand, and Bioplant ${ }^{\circledR}$ (2:1:1), and kept in a greenhouse under $40 \%$ shade cloth. During the experiment, the plants were protected from rain by a plastic cover.

At the start of the experiment $\left(\mathrm{T}_{0}\right)$, the pots were divided into two groups as follows: Group 1 - control, with plant irrigation maintained at $70 \%$ of the water retention capacity; and Group 2 - subject to stress, where irrigation was suspended until the photosynthetic rate neared zero $\left(1^{\text {st }} \mathrm{P}_{0-} 41\right.$ days after the beginning of the experiment). This was followed by a period in which the plants were once again subjected to daily irrigation for 12 days, maintaining $70 \%$ of the water retention capacity, until the levels of photosynthetic rates of the Group 2 plants subjected to irrigation suspension presented values close to those of the control. A second cycle of irrigation suspension/reirrigation ( $\mathrm{S} / \mathrm{R})$ was then carried out $\left(1^{\text {st }} \mathrm{S} / \mathrm{R}-53\right.$ days after the beginning of the experiment) and the seedlings were evaluated when zero photosynthesis was observed ( $2^{\text {nd }} \mathrm{P}_{0}-78$ days after the beginning of the experiment).

To evaluate the effect of intermittent water deficit, the plants were monitored every two days, until the photosynthetic rates were close to zero. The plants were then rehydrated daily for one week, and then the following characteristics were evaluated:

- Relative chlorophyll content: Obtained with the help of a chlorophyll meter (Konica Minolta, SPAD 502).

- Gas exchanges: The photosynthetic rate - A $\left(\mu \mathrm{mol} \mathrm{m} \mathrm{m}^{-2} \mathrm{~s}^{-1}\right)$, foliar transpiration $-\mathrm{E}\left(\mathrm{mmol} \mathrm{m} \mathrm{m}^{-2} \mathrm{~s}^{-1}\right)$, stomatal conductance - Gs $\left(\mathrm{mol} \mathrm{m} \mathrm{m}^{-2} \mathrm{~s}^{-1}\right)$, and internal

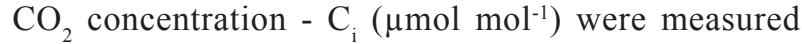
using an infrared gas analyzer (IRGA) (Model LCi PRO; Analytical Development Co. Ltd., Hoddesdon, UK). The measurements were performed on three seedlings per treatment between 08:00 $\mathrm{h}$ and 11:00 $\mathrm{h}$, and were recorded from two fully extended previously marked leaves. All measurements were taken from these marked leaves. Only the data measured under a photosynthetic photon flux (PPF) above $700 \mathrm{mmol} \mathrm{m}^{-2} \mathrm{~s}^{-1}$ were considered. From the gas exchange data, the following ratios were calculated: instantaneous water-use efficiency (WUE $\mu \mathrm{mol} \mathrm{mmol}^{-1}$ ), intrinsic water-use efficiency (IWUE $\mu \mathrm{mol} \mathrm{mol}^{-1}$ ), and instantaneous carboxylation efficiency $\left(\mathrm{A} / \mathrm{C}_{\mathrm{i}} \mu \mathrm{mol} \mathrm{m} \mathrm{m}^{-2} \mathrm{~s}^{-1}\right.$

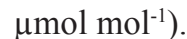

- Leaf water potential $(\Psi \mathrm{w})$ : Obtained from readings performed on the second pair of fully extended leaves from the apex to the base, between 10:00 $\mathrm{h}$ and 11:00 h, using a Scholander pressure chamber (Portable Plant water status console - model 3115) (Scholander et al., 1964), immediately after leaf collection. The values were obtained in bars and later converted to MPa.

To determine the activity of the antioxidant enzymes, extracts were obtained by homogenization of $1 \mathrm{~g}$ of leaves from each treatment, which were initially fragmented in a mortar in the presence of liquid nitrogen. Then, $2 \mathrm{~mL}$ of extraction solution was added, consisting of $0.1 \mathrm{mM}$ EDTA in $0.1 \mathrm{M} \mathrm{pH} 6.8$ potassium phosphate buffer containing $20 \mathrm{mg}$ of polyvinylpyrrolidone, before further homogenization. The activities of the antioxidant enzymes superoxide dismutase (SOD), peroxidase (POX), and catalase were measured following the methodology compiled by Broetto (2014).

To analyze the gas exchanges, the design was completely randomized with four repetitions of the two water regimes (control - irrigated periodically and stress), in which each value corresponded to one seedling. The results were submitted to analysis of variance and where there was a statistical significance, the means of each treatment were submitted to a $t$ test at $5 \%$ probability in the Sisvar statistical program.

For the remaining analyses, a completely randomized factorial design was used for both water regimes (control - irrigated periodically and stress) $\times$ four evaluation periods (time zero - $\mathrm{T}_{0}$; first and second photosynthesis $-1^{\text {st }} \mathrm{P}_{0}$ and $2^{\text {nd }} \mathrm{P}_{0}$; first cycle of irrigation suspension/rehydration ( $\left(1^{\text {st }} \mathrm{S} / \mathrm{R}\right)$ and four repetitions, in which each value corresponded to one seedling. The results were submitted to analysis of variance and statistical effect of water regimes; the averages were compared using $t$ 
tests, whereas the interaction between the treatments were compared using the Scott Knott test, both at 5\% probability in the Sisvar statistical program.

\section{RESULTS AND DISCUSSION}

The water potential $\left(\Psi_{\mathrm{w}}\right)$ was strongly influenced by the water regime, since the greatest water potential reduction (-2.0 to $-2.5 \mathrm{MPa}$ ) occurred when photosynthesis reached values near to zero while in the control, the average value was $-0.65 \mathrm{MPa}$ (Figure 1).

Seedlings of $S$. terebinthifolius under restricted water conditions demonstrated reduced water potential $\left(\Psi_{\mathrm{w}}\right)$, with average values of -2.0 to $-2.5 \mathrm{MPa}$ when the photosynthetic rates were reduced to values near zero $\left(1^{\text {st }}\right.$ and $2{ }^{\text {nd }} \mathrm{P}_{0}$ ), showing a loss of turgidity in the leaves. When plants lose water at a greater rate than their absorption and transport capacity, $\Psi_{\mathrm{w}}$ is reduced, stomata close, and photosynthesis is reduced (Costa; Marenco, 2007); these phenomena were all observed in this study.

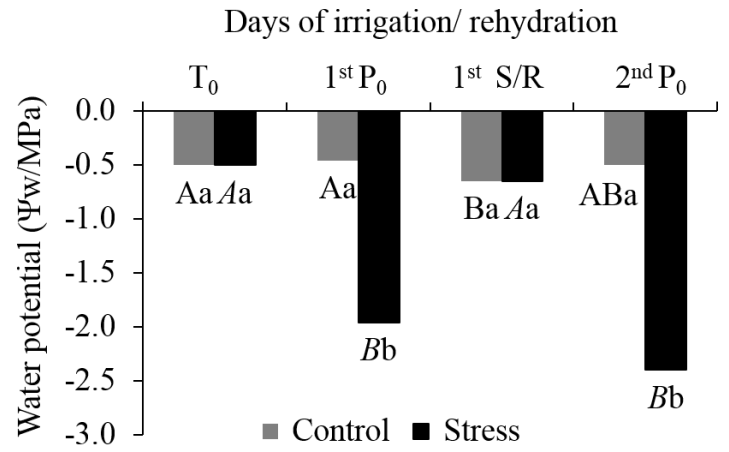

Figure 1: Average values of water potential $\left(\Psi_{W}\right)$ of seedlings of Schinus terebinthifolius Raddi submitted to intermittent water deficit. Lowercase letters represent treatments (stressed plants and control), capital letters represent control, and capital letters in italics represent the stressed seedlings within the evaluation periods.

Reduction in $\Psi_{\mathrm{W}}$ may lead to a decrease in photosynthetic activity, as observed in Campomanesia xanthocarpa seedlings under water restriction. The seedlings showed a reduction of the water potential $\left(\Psi_{\mathrm{w}}\right)$, reaching an average value of $-2.4 \mathrm{MPa}$, when the photosynthetic rate was reduced to values close to zero, displaying the loss of leaf turgescence (Bento et al., 2016). This was also observed in the S. terebinthifolius plants, since the intrinsic carboxylation efficiency $(\mathrm{A} / \mathrm{Ci})$ of the Rubisco enzyme decreased with the decrease in $\Psi \mathrm{w}$, which reached -2.0 MPa after 41 days of suspended irrigation.
The photosynthesis rates (A) were lower in stressed plants than in the controls. Upon rehydration, these values increased; however, they did not reach the values observed for the control plants (Figure 2a). This was also observed for the transpiration rate $(\mathrm{E})$, in that the values remained lower for the stressed plants than for the control plants even after the $1^{\text {st }}$ period of suspension/rehydration (Figure $2 b$ ).

Water use efficiency (WUE) oscillated throughout the evaluation, with the greatest values observed in the control seedlings (Figure 2c). The lowest value for WUE occurred when photosynthesis initially approached zero $\left(1^{\text {st }}\right.$ $\mathrm{P}_{0}-41^{\text {st }}$ day), and recovery was observed during rehydration ( $\left.1^{\text {st }} \mathrm{S} / \mathrm{R}\right)$, following which a fall in WUE occurred due to the second period of zero-value photosynthesis $\left(2^{\text {nd }} \mathrm{P}_{0}\right)$.

The internal concentration of $\mathrm{CO}_{2}(\mathrm{Ci})$ was greater in the stressed plants, which induced lower instantaneous carboxylation efficiency $(\mathrm{A} / \mathrm{Ci})$, resulting in values that were close to zero 41 days after the irrigation suspension. This was a period during which the stomatal conductance (Gs) also showed the lowest values (Figures 3a, b and c). Subsequently, these values increased following rehydration. The behavior of these three characteristics varied in the two periods of water restrictions. With less water availability, there was a reduction of Gs, however the $\mathrm{C}_{\mathrm{i}}$ remained high until day 38 according to the smaller $\mathrm{A} / \mathrm{Ci}$. However, with the second suspension of irrigation, these characteristics were reduced by 78 days after the start of the experiment. Similar results for WUE, Gs, $\mathrm{Ci}$ and $\mathrm{A} / \mathrm{Ci}$ were also observed by Junglos et al. (2016) in Campomanesia adamantium seedlings under water restriction, but in this species, it took only 31 days for the level of photosynthesis to approach zero.

The IWUE (A/Gs) of the control and stressed plants was similar, such that at 64 days (23 days after rehydration) it was significantly higher in the stressed plants than in the control plants (Figure 3d). At 15 days after the second period of suspended irrigation (68 days), both the WUE and the IWUE decreased significantly in the stressed plants.

The $S$. terebinthifolius seedlings presented low tolerance to hydric deficiency in the soil, with elevated sensitivities for A, Gs, E, and $\Psi$ w. Characteristics of wateruse economy under stressful conditions were not observed since the WUE and IWUE also decreased during these critical periods. This suggests that stomatal closure (data not shown) did not maintain IWUE under water stress conditions, since these relationships should have remained high. The capacity of plants to restore photosynthetic activity after rehydration is of fundamental importance, as is the capacity to avoid and/or support hydric stress. 


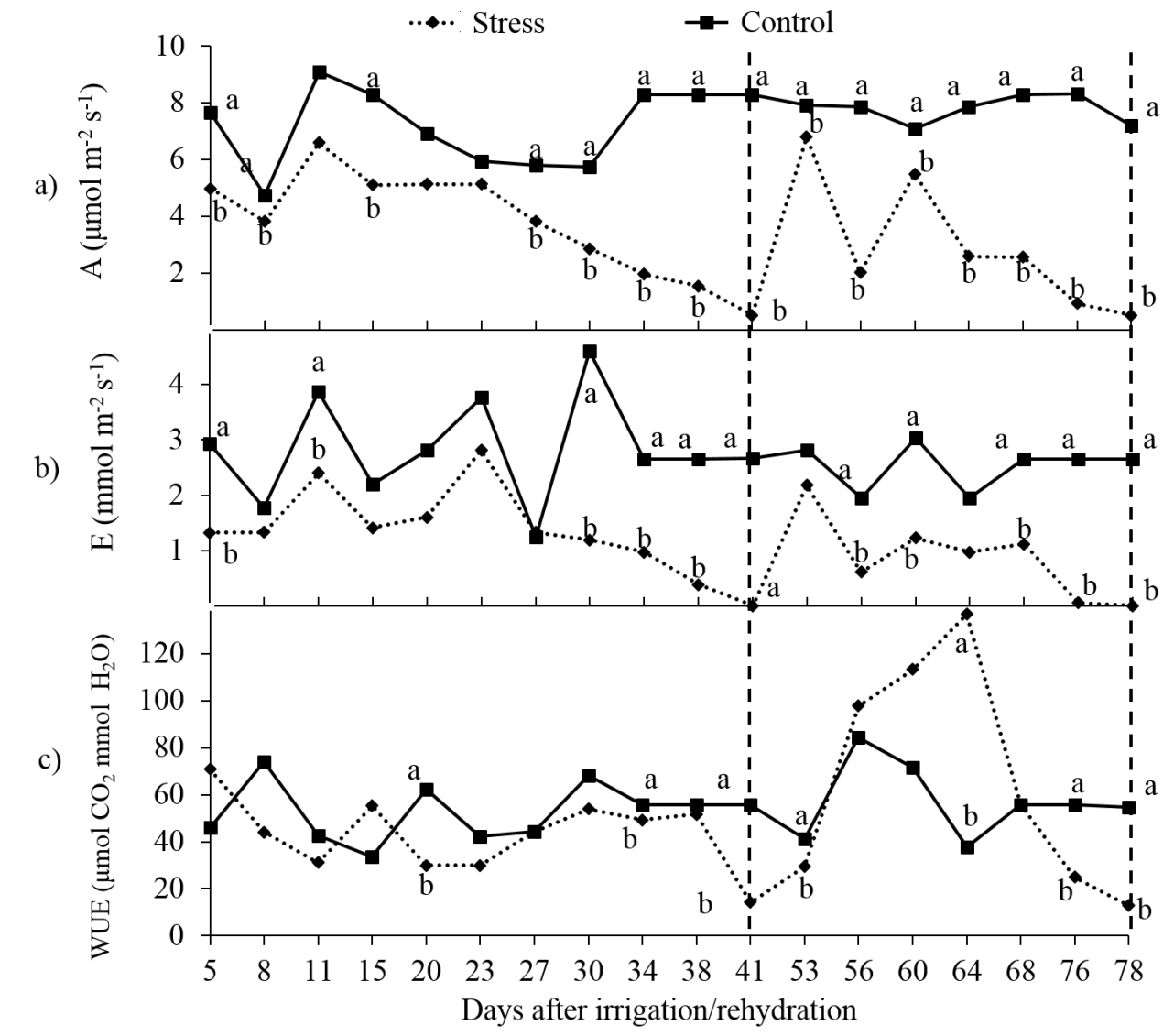

Figure 2: Average values of photosynthetic rate - A (a), transpiration rate - E (b), water use efficiency - WUE (c) of seedlings of Schinus terebinthifolius Raddi submitted to intermittent water deficit. Means followed by different letters differ by $t$ test at $5 \%$ probability. The dashed lines represent the photosynthesis levels next to zero (41 and 78 days).

Under conditions of low water availability, stomatal closure, caused by elevated levels of ABA, constitutes one of the first strategies used by plants to decrease the transpiration rate and maintain cellular turgidity (Melcher et al., 2009). Stomatal closure reduces stomatal conductance and limits the assimilation of $\mathrm{CO}_{2}$ (Ashraf; Harris, 2013). Beyond these responses, under severe hydric stress, dehydration of the mesophilic cells and inhibition of the metabolic basis of photosynthesis takes place (Ashraf; Harris, 2013).

In our study, the relative chlorophyll content was reduced by the stress associated with water deficit. The lowest values were observed during the periods when the seedlings reached near-zero photosynthesis $\left(1^{\text {st }} \mathrm{P}_{0}\right)$ and did not recover following irrigation $\left(1^{\text {st }} \mathrm{S} / \mathrm{R}\right)$ after the second period of zero photosynthesis $\left(2^{\text {nd }} \mathrm{P}_{0}\right)$ (Figure 4$)$. The decreased relative chlorophyll content observed in stressed plants, even after the re-establishment of irrigation, suggests that the drought caused not only substantial damage to photosynthetic pigments, but also lead to deterioration of thylakoid membranes (Anjum et al., 2011; Kannan; Kulandaivelu, 2011). The reduced chlorophyll levels in the leaves might affect photosynthesis (Ashraf; Harris, 2013). In the present study, chlorophyll degradation appears to have occurred in the S. terebinthifolius plants, as they showed typical signs of chlorosis.

The activity of antioxidant enzymes in the aerial part and roots of the seedlings was greater in the stressed plants than in the control plants. The SOD activity was greater in the aerial part in the $2 \mathrm{nd}_{0}$ and in the root in the 1 st $\mathrm{P}_{0}$. The greatest POX activity was observed in the aerial part in the 1 st $\mathrm{P}_{0}$ and in the roots in the 1st and 2nd $\mathrm{P}_{0}$. For CAT, the greatest activity was observed in both the leaves and roots in the 1 st $\mathrm{P}_{0}$ (Figure 5a-f). 
a)

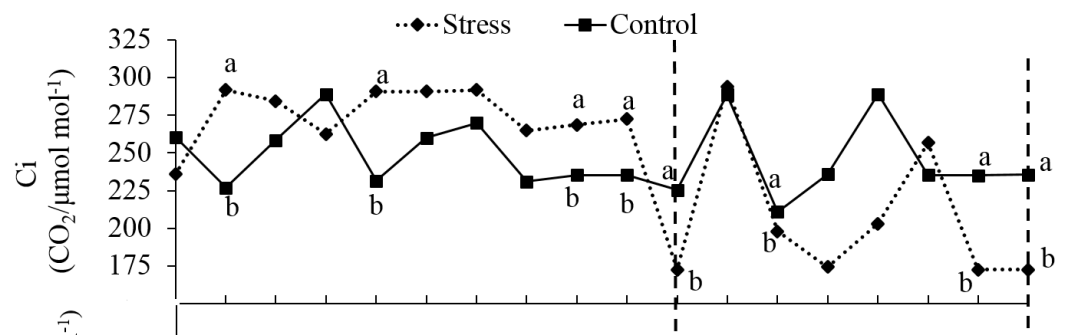

b)

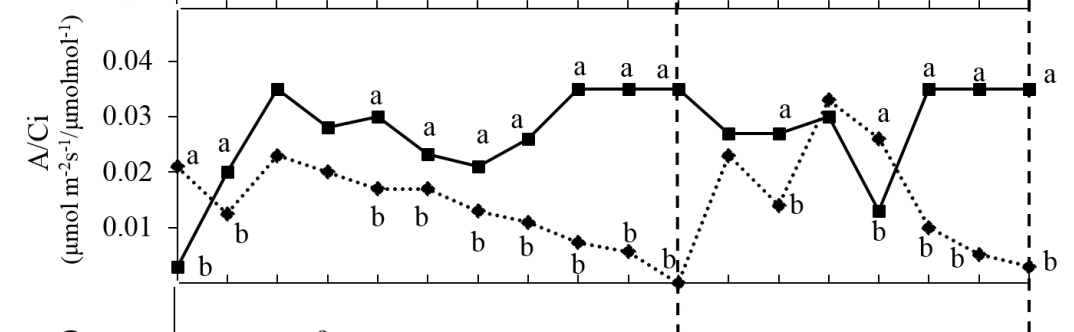

c)

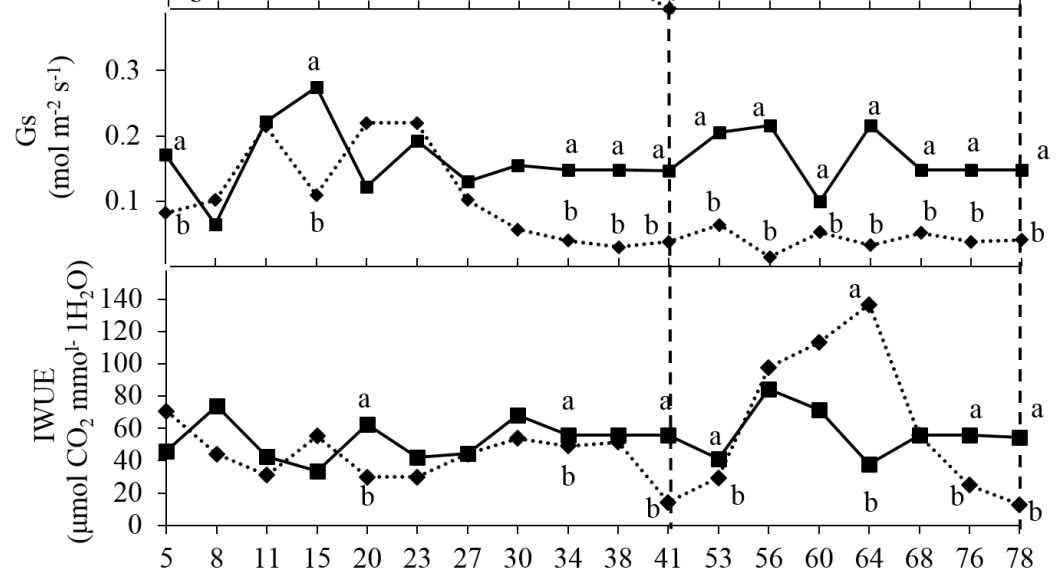

Days after irrigation/rehydration

Figure 3: Mean values of internal $\mathrm{CO}_{2}$ concentration - $\mathrm{Ci}(\mathrm{a})$, instantaneous carboxylation efficiency of $\mathrm{CO}_{2}-\mathrm{A} / \mathrm{Ci}(\mathrm{b})$, stomatal conductance - Gs (c) and intrinsic efficiency of water use - IWUE (d) of seedlings of Schinus terebinthifolius submitted to intermittent water deficit. Means followed by different letters differ by $t$ test at $5 \%$ probability. The dashed lines represent the photosynthesis levels next to zero (41 and 78 days).

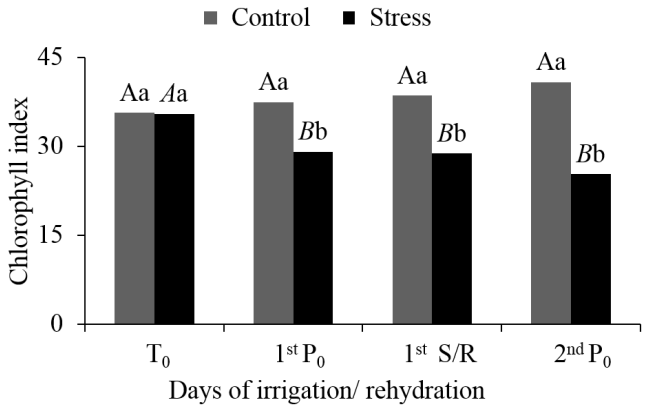

Figure 4: Mean values of relative chlorophyll content (SPAD) of seedlings of Schinus terebinthifolius Raddi submitted to intermittent water deficit. Lowercase letters represent treatments (stressed plants and control), capital letters represent control, and capital letters in italics represent the stressed seedlings within the evaluation periods.
The increased SOD, POX, and CAT activity in the aerial part and root system of the $S$. terebinthifolius plants suggests that the intermittent water deficit causes oxidative stress and that the changes in these enzymes represent a protective mechanism. Evidence in the literature indicates that the activity of one or more antioxidant enzymes, such as SOD and POX, is observed in plants exposed to stressful conditions, and their increased activity might be related to increased stress tolerance (Allen; Webb; Schake, 1997). Together with other physiological mechanisms, the efficiency of the antioxidant system increases the tolerance capacity of the plant by decreasing the effects of ROS (Giannakoula et al., 2010). The plants subjected to stress were able to modulate their defense response by producing antioxidant enzymes in order to overcome the stress and restore normal metabolism (Soares; Machado, 2007). 
- Control Stress

a)

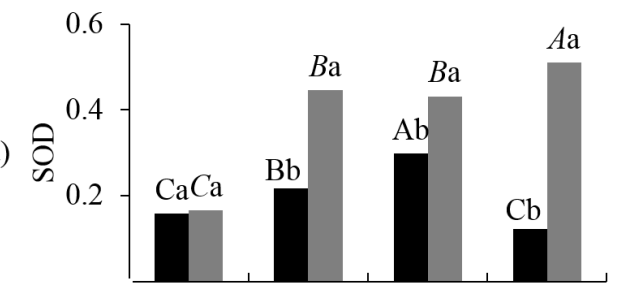

c)

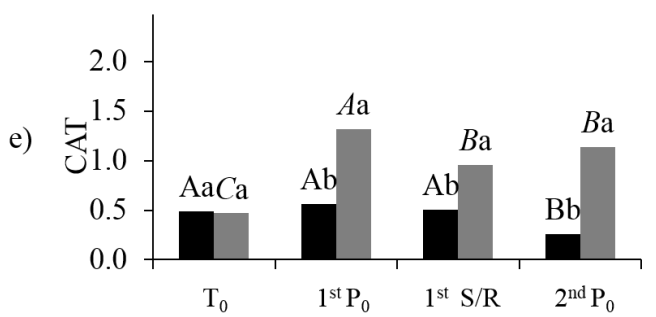

Days after irrigation/rehydration
- Control Stress

b)

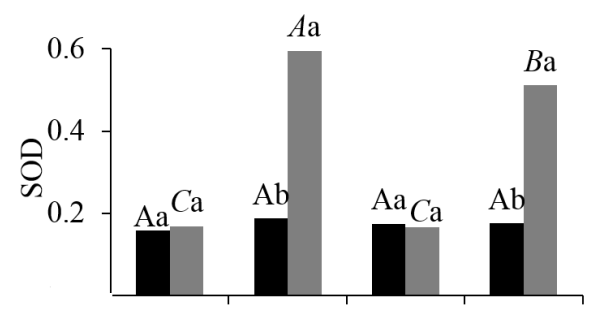

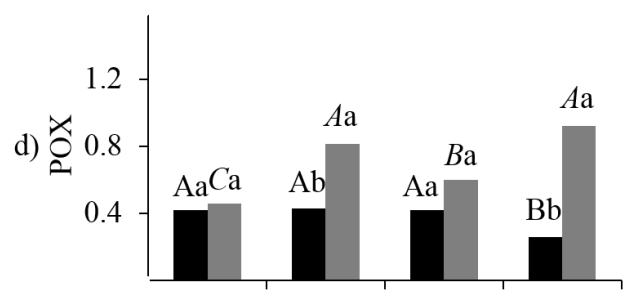

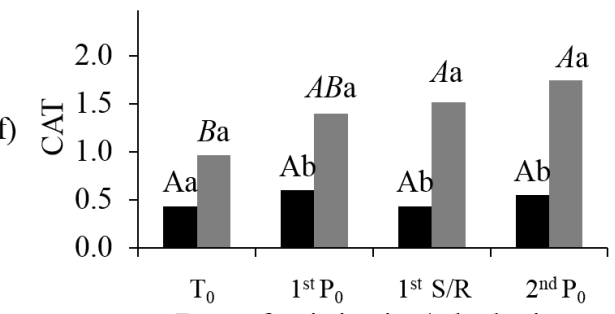

Days after irrigation/rehydration

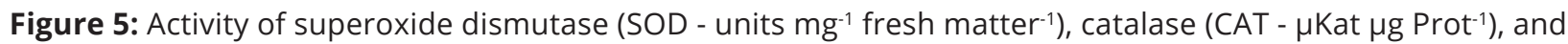
peroxidase (POX - $\mu$ Kat $\mu$ Prot $\left.^{-1}\right)$ in the aerial part $(a, c, e)$ and roots $(b, d, f)$ of seedlings of Schinus terebinthifolius Raddi submitted to intermittent water deficit. Lowercase letters represent treatments (stressed plants and control), capital letters represent control, and capital letters in italics represent the stressed seedlings within the evaluation periods.

\section{CONCLUSIONS}

Water stress significantly reduced photosynthesis, stomatal transpiration conductance, and chlorophyll content of $S$. terebinthifolius plants. The plants recovered the carboxylation efficiency of Rubisco, but not the photosynthetic rate after rehydration. Activity of antioxidant enzymes increased both in the aerial part and the root in response to water deficit.

\section{ACKNOWLEDGMENTS}

The authors are grateful for the financial support by FUNDECT-MS (Fundação de Apoio ao Desenvolvimento do Ensino, Ciência e Tecnologia do Estado de Mato Grosso do Sul) and PNPD/CAPES (Programa Nacional de PósDoutorado/Coordenação de Aperfeiçoamento de Pessoal de Nível Superior).

\section{REFERENCES}

ALI, Q.; ASHRAF, M. Induction of drought tolerance in maize (Zea mays L.) due to exogenous application of trehalose: Growth, photosynthesis, water relations and oxidative defence mechanism. Journal Agronomy and Crop Science, 197(4):258-271, 2011.

ALLEN, R. D.; WEBB, R. P.; SCHAKE, S. A. Use of transgenic plants to study antioxidant defenses. Free Radical Biology and Medicine, 23(3):473-479, 1997.

ANJUN, S. A. et al. Morphological, physiological and biochemical responses of plants to drought stress. African Journal of Agricultural Research, 6:2026-2032, 2011.

ASHRAF, M.; HARRIS, P. J. C. Photosynthesis under stressful environments: An overview. Photosynthetica, 51:163190, 2013. 
BENTO, L. F. et al. Potential for recovery of Campomanesia xanthocarpa Mart. ex O. Berg seedlings from water deficit. African Journal of Agricultural Research, 11(30):27752785, 2016.

BROETTO, F. Métodos de trabalho em bioquímica vegetal e tecnologia de enzimas. [Recurso Eletrônico]/ Coordenador: Fernando Broetto - Botucatu: IBB, Cultura. Acadêmica, UNESP, São Paulo. 2014. 92p.

CARVALHO, M. G. et al. Schinus terebinthifolius Raddi: Composição química, propriedades biológicas e toxicidade. Revista Brasileira de Plantas Medicinais, 15(1):158-169, 2013.

COSTA; G. F.; MARENCO, R. A. Fotossíntese, condutância estomática e potencial hídrico foliar em árvores jovens de andiroba (Carapa guianensis). Acta Amazonica, 37(2):229-234, 2007.

DAMAYANTHI, M. M. N.; MOHOTTI, A. J.; NISSANKA, S. P. Comparison of tolerant ability of mature field grown tea (Camellia sinensis L.) cultivars exposed to drought stress in Passara area. Trop Agricultural Reserch, 22:66-75, 2010.

GIANNAKOULA, A. et al. Aluminum stress induces up-regulation of an efficient antioxidant system in the Al-tolerant maize line but not in the $\mathrm{Al}$ sensitive line. Environmental and Experimental Botany, 67:487-494, 2010.

JUNGLOS, F. S. et al. Recovery of the photosynthetic capacity of Campomanesia adamantium (Myrtaceae) after water deficit. Brazilian Journal of Botany, 39(2):541-546, 2016.
KANNAN, N. D.; KULANDAIVELU, G. Drought induced changes in physiological, biochemical and phytochemical properties of Withania somnifera Dun. Journal of Medicinal Plants Research, 5:3929-3935, 2011.

KARUPPANAPANDIAN, T. et al. Reactive oxygen species in plants: Their generation, signal transduction, and scavenging mechanisms. Australian Journal of Crop Science, 5(6):709-725, 2011.

MELCHER, K. et al. A gate-latchlock mechanism for hormone signalling by abscisic acid receptors. Nature, 462:602608, 2009.

OLIVEIRA, C. J.; ARAUJO, T. L. Plantas medicinais: Usos e crenças de idosos portadores de hipertensão arterial. Revista Eletrônica de Enfermagem, 9(1):93-105, 2007.

SCHOLANDER, P. F. et al. Hydrostatic pressure and osmotic potential in leaves of mangroves and some other plants. Proceedings of the National Academy of Sciences, 52:119-125, 1964.

SOARES, A. M. S.; MACHADO, O. L. T. Defesa de plantas: Sinalização química e espécies reativas de oxigênio. Revista Trópica, 1(1):9-19, 2007.

SOUZA, S. C. M.; PIÑA-RODRIGUES, M. C. F. Desenvolvimento de espécies arbóreas em sistemas agroflorestais para recuperação de áreas degradadas na Floresta Ombrófila Densa, Paraty, RJ. Revista Árvore, 37(1):89-98, 2013. 